Western University Scholarship@Western

Centre for the Study of International Economic Centre for the Study of International Economic

Relations Working Papers

Relations

1988

\title{
National Product Functions in Comparative Steady-State Analysis
}

Richard Manning

James R. Markusen

Follow this and additional works at: https://ir.lib.uwo.ca/economicscsier_wp

Part of the Economics Commons

Citation of this paper:

Manning, Richard, James R. Markusen. "National Product Functions in Comparative Steady-State Analysis." Centre for the Study of International Economic Relations Working Papers, 8808C. London, ON: Department of Economics, University of Western Ontario (1988). 


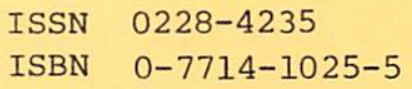

THE CENTRE FOR THE STUDY OF INTERNATIONAL ECONOMIC RELATIONS

WORKING PAPER NO. $8808 \mathrm{C}$

\author{
NATIONAL PRODUCT FUNCTIONS IN COMPARATIVE \\ STEADY-STATE ANALYSIS
}

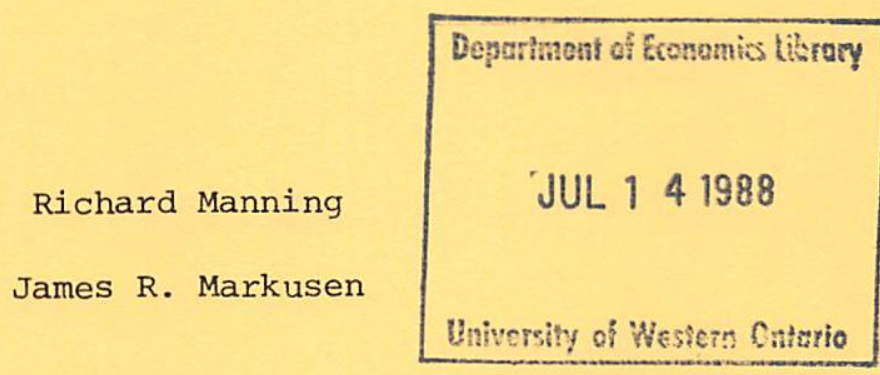

This paper contains preliminary findings from research work still in progress and should not be quoted without prior approval of the author.

DEPARTMENT OF ECONOMICS

THE UNIVERSITY OF WESTERN ONTARIO

LONDON, CANADA

N6A 5 C2 2 


\title{
NATIONAL PRODDCT FUNCTIONS IN COMPARATIVE
}

\section{STEADY-STATE ANALYSIS}
R. Manning
and
Jame s R. Ma rku sen
SUNY at Buffalo
University of Western Ontario

\begin{abstract}
The structural properties of steady states are well understood for multisector models, but the comparative dynamics of longran growth are much less developed. By exploiting duality theory, this paper obtains conclusions about these effects for a sma11, internationally-trading, economy. Arbitrary numbers of consumption and capital goods, and a very general technology, are admitted. Definite conclusions about the shortrun and longrun impact on ontputs and factor prices are not always available. Some correlations can be established between vectors of parameter changes and endogeneous variable changes, however. To confirm that some correlations hold it is necessary to impose strong assumptions.
\end{abstract}

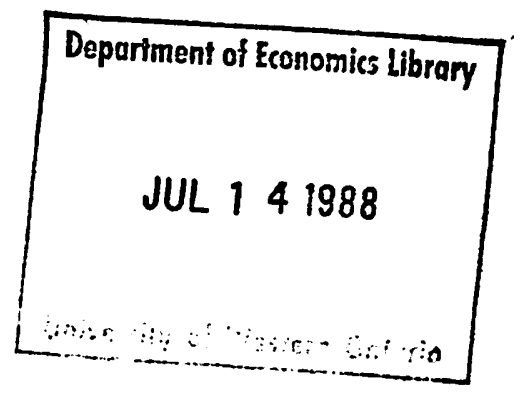




\section{Introduction}

The comparative dynamic properties of a multisectoral model of economic growth and international trade are investigated. The economy is assumed to face world prices (or changes in world prices) that are given, and to be in ar equilibriun steady state (or to change between such states). Results are obtained comparing the shortrun and longrun effects on output and factor rewards of changes in world prices, primary resource endowments, time preference, and taxes. Even with the strong simplifying assumptions about prices and steady-state growth it is, in general, impossible to get results which describe the impact of a particular parameter change on a particular endogeneous variable. What can be established is the correlation between vectors of parameter changes and endogeneous variable changes. Some correlations hold quite generally, but others can be established only on strong assumptions about the technology and the relationships between factors.

Many papers have been written on the topic of economic growth and international trade. These papers have, for the most part, been designed to make specific points, and they develop models accordingly. Simple models which illustrate the consequences of capital accumalation for an open economy have been analyzed by Bruce (1977), Inada (1968), Johnson (1971), Oniki and Uzawa (1965) and Stiglitz (1970): In these models a single capital good is used, with labor, to produce several tradeable commodities, one of which is new capital. Educational policy, which concerns the accumalation of human capital, was considered by Manning (1982) in a structurally similar model. Still simpler models have been used to discern the effects of international capital movements on economic growth. Long (1973), Manning (1975), Negishi (1965) and Ruffin (1979, 1985) developed models in which capital and labor 
produce a single al1-purpose commodity. No commodity trade occurs. The only international transactions are capital flows and interest payments. More complex models have been presented by Acheson (1970), Ethjer (1979), Kemp and Khang (1974), Petith (1976) and Samuelson (1975). These models were designed to illustrate particular features of the timing of investment and the structure of froduction: Although they recognize more than ore capital good they are not completely general.

From the existing literature many results are known about economic growth and international trade. Few general results are available, however. It is not known which conclusions rest on details of the economic structure and which hold generally. With the malti-sectoral model developed in this paper it is possible to distingnish between these kinds of result, and to identify the type of conditions needed for particular conclusions.

Any number of consumer goods, any number of capital goods, any number of primary resources, and a very general technology, are admitted in the economy that is considered. The economy is assumed to be in a steady state in which identical consumers are maximizing (the present value of) their utility. This is in contrast to many of the papers cited above: It is commoniy assumed that savings obey a simple behavioural rule (savings are a constant fraction of national income, for example).

For closed economies, the analysis of malti-sectoral optimal (or equilibrium) growth models is well advanced. It is known that there may not be a steady-state equilibrium for these economies. McKenzie (1976) showed that only if time preference is sufficiently 10 will a steady state be achieved. In an important paper. Benhabib and Nishimura (1979) demonstrated that the economy approaches an endless cycle if the rate of time preference exceeds a critical value. 1 Although prices are endogeneousiy determined for 
a closed economy, the possibility of cyclic growth in a small, ofen, multi-sector economy cannot be ruled out. (Indeed, Benhabib and Nishimura's investigation of the stability properties of the economy assumed that prices were constant in a neighbourhood of the steady state.) Implicit, therefore, in the present formalation of the trade and growth problem is an assumption that parameter values (time preference in particular) admit a steady state as the longran equilibrium.

We11-known properties of the national product function are exploited here to analyse the multisectoral model. Dixit and Norman (1980) popularized the "dual" approach to international trade theory, bot the present analysis is closest to that of Woodland (1982, Chapters 14 and 15) who treated the problem of economic growth and international trade with the techniques of duality theory. As previously noted, precise conclusions about the effects of parameter changes are not fonnd here; correlations are discovered instead. These are of the same sort as presented in different conterts by Neary (1985), Markusen and Svensson (1985), and Neary and Ruane (1985).

Issues more general than those commonly considered in international trade theory are dealt with here. To some extent, the analysis also extends earlier work on the longrun effects of taxes on capital. Feldstein (1974a, 1974b) rorked out the incidence of a tax on capital, using a model with a single capital good. Host subsequent analyses have retained this structure. When capital tares are allowed in the multisectoral model, more general conclusions about their effects become avajable than have previously been found.

\section{The Economy}

To begin, no taxes are allowed. These will be introduced later, after 
developing and analysing the economy in their absence. The small, ofen, economy has available n primary resources, which are used with m capital goods to produce $l$ final (consumer) goods and m investment goods. These inputs and outputs are related by a transformation equation:

$$
T(y, x, k, v)=0
$$

where $y$ is the vector of final goods outputs, $I$ is the vector of investment goods outputs, $k$ is the vector of capital stocks, $v$ is the vector of primary resources, ${ }^{2}$ and $T$ is increasing in all its arguments. Various restrictions may usefully be imposed on $T$ :

(T1) I is strictly angsi-conyex in y and $x:$

(T2) I is strict1y quasi-convex in $k_{\text {i }}$

(T3) I is strictly qugsi-convex in $\mathrm{Vi}$

(T4) $T(\lambda, 2, \lambda, \lambda k, \lambda v)=0$, for $811 \lambda>0$. These require, respective1y, that the production-possibility set is strictly conver, that there are diminishing returns to capital, that there are diminishing returns to primary resources, and that there are constant returns to scale.

Althongh there is no need to explain the transformation equation in more basic terms, some examples may help to relate it to the underlying production conditions. Suppose, for instance, that there are two commodities produced according to homogeneous of degree one, quasi-strictly concave, production functions which have as inputs capital and labor. If factor intensities differ between sectors, then $T 1, T 2, T 3$ and $T 4$ are satisfied. Alternatively, suppose that each commodity is produced according to a strictly concave production function (so there are both decreasing returns to scale and a diminishing rate of factor substitution): Then T1, T2 and T3 are satisfied, but T4 is not. 
Let $p$ be the vector of final goods prices, and q the vector of capital goods prices. The value of output is $p^{\prime} y+q^{\prime} x$ (where' denotes transpose). Competitive behaviour ensures that this is maximized.

DEFINITION 1: The gross national product function is given by

$$
G(p, q, k, v)=\frac{\text { Maximum }}{y, x}\left[p^{\prime} y+q^{\prime} x: T(y, x, k, v)=0\right\}
$$

It is we11-known that $G$ is homogeneous of degree one, and convex, in $p$ and $q$. In addition, under $T 2 G$ is strictly concave in $k$, while under $T 3 G$ is strictly concave in $v$. Onder $T 2$ and $T 3 G$ is concave in $k$ and $v$ jointly. Fur thermore, under T1,

$$
y=G_{p} \text { and } x=G_{q}
$$

and also

$$
r=G_{k} \text { and } w=G_{v}
$$

where $G_{p}$ is the vector of derivatives of gross national product with respect to final goods prices, $G_{q}, G_{k}$ and $G_{v}$ are similarly defined, $I$ is the vector of rentals of capital, and $w$ is the vector of primary resonrce prices. The results stated in (2) and (3) are intuitive. For example, a one nnit increase in a particular capital stock will permit an increase in gross national product. This increase is the marginal value of that capital good, Which, in a competitive market, is its rental price.

Primary resources are assumed to be in fired supply. The shortrun is defined to be a period in which the capital stocks are fixed independently of economic considerations: Comparative static effects are developed directly from the gross national product function on this assumption. In the longrun, the size of capital stocks depends on their contribution to the we11-being of their owners. 
Let $c$ be the rate of consumption of final goods by consumers in the economy, and let $s$ be their rate of gross investment in capital goods. 3 These are 1 imited by the budget constraint

$$
p^{\prime} c+q^{\prime} s=p^{\prime} y+q^{\prime} x
$$

Installed capital is assumed to be internationally immobile, and no lending occurs, so the budget constraint requires that the value of current expenditure equals the value of current production. Capital stocks evolve according to

$$
\dot{k}=s-D(\delta) k
$$

where $\vec{k}$ is the vector of rates of change of capital stocks, and $D(\delta)$ is a diagonal matrix with its ith diagonal element the exponential rate of depreciation of the ith capital stock.

The following is assumed about decision-making in the economy:

(J) Capital is accomulated as if there is a single consmer whe maximizes

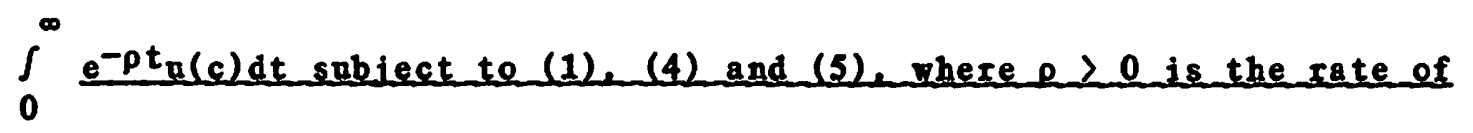
time preference and $n$ is a strictly concare instantaneons ntility function.

This implies a path through time for consumption, gross investment, and capital stocks. In the 1 imit as time tends to infinity, the longrun values of these variables are obtained. The work of Benhabib and Nishimura shows that longrun values need not be constants: But if they are constants, the economy has achieved a steady state. The following is assumed:

(S) The longrun equilibring for the economy is a steady state, PROPOSITION 1: Dnder T1, T2, U and $S$ in the longrun

$$
\mathbf{G}_{\mathbf{k}}=\mathbf{D}(p+\delta) q
$$


If $G$ is toice differentiable and $G_{k k}$ is non-singulare then the longrun capital stocks are determined by a differentiable function $K(p, q, \nabla, \rho)$ for which

$$
\begin{aligned}
& \mathbf{K}_{\mathbf{p}}=-\mathbf{G}_{\mathbf{k k}}^{-1} \cdot \mathbf{G}_{\mathbf{k p}} \\
& K_{q}=-G_{k k}^{-1} \cdot\left(G_{k q}-D(p+\delta)\right) \\
& \mathbf{K}_{\mathbf{v}}=-\mathbf{G}_{\mathbf{k k}}^{-1} \cdot \mathbf{G}_{\mathbf{k v}} \\
& K_{\rho}=G_{k k}^{-1} \cdot q
\end{aligned}
$$

Proof: Let $e^{-\rho t_{\mu_{1}}}$ and $e^{-\rho t_{\mu_{2}}}$ be the multipliers associated with (1) and (4) and let $e^{-\rho t_{\lambda}}$ be the co-state variable for (5). Then necessary (and sufficient, in view of the assumptions of concavity) conditions for the problem O include:

$$
\begin{aligned}
& u_{c}-\mu_{2} p=0 \\
& \lambda-\mu_{2} q=0 \\
& \mu_{2} p-\mu_{1} T_{y}=0 \\
& \mu_{2} q-\mu_{1} T_{x}=0 \\
& \dot{\lambda}=D(p+\delta) \lambda+\mu_{1} T_{k}
\end{aligned}
$$

Now (13) and (14) imply that gross national product is maximized. From Definition 1,

$$
G_{k}=-p_{i} T_{k} / T_{y i}, i=1, \ldots, k
$$

Using this in (13) implies that

$$
-\mu_{2} G_{k} / \mu_{1}=T_{k}
$$

In a steady state $\dot{\lambda}=0$. Then (6) follows from (12), (15) and (16).

Since $G_{k k}$ is non-singular, then $G_{k k}^{-1}$ exists. 4 The implicit function theorem can then be applied to (6) to ensure the existence of a differentiable function $K(p, q, v, p)$, with derivative (7), (8), (9) and (10). 
The longrun behaviour of capital stocks is described in Proposition 1. By substituting into the gross national product function, the longrun (steady-state) gross national product function $G(p, q, R(p, q, v, p), v)$ is obtained. From this can be calculated the longrun responses of the endogeneous output and price variables to parameter changes.

\section{Shortrun and Longrun Responses to Price Changes.}

By differentiating (2) the shortrun outpat responses to price changes are found.

PROPOSITION 2: If I1 applies then there is a non-negative corcelation between the price changes and the vector of ontput changes in the shortrng: That is $d p^{\prime} d y \geq 0$ and $d q^{\prime} d x \geq 0$

Proof: From (2)

$$
\left[\begin{array}{l}
d y \\
d x
\end{array}\right]=\left[\begin{array}{ll}
G & G \\
G & G_{p q} \\
G q p & q q
\end{array}\right]\left[\begin{array}{l}
d p \\
d q
\end{array}\right]
$$

Therefore

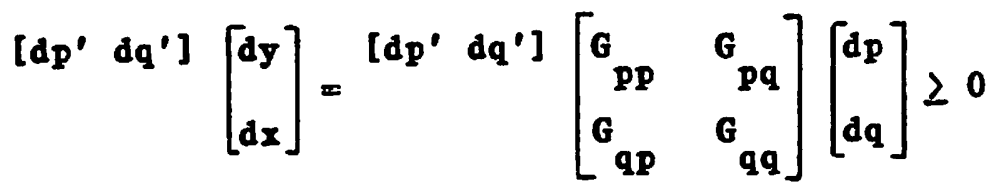

since $G$ is convex in $p, q$, which implies that $\left[G_{i j}\right]$ is positive semi-definite.

Nothing new is involved in this Proposition. It is given as a basis of comparison for the longrun effects of price changes. Denote by $Y$ and $X$ the longrun outputs of $f$ inal and investment goods. From the longran gross national product function 


$$
\left[\begin{array}{l}
d Y \\
d X
\end{array}\right]=\left[\begin{array}{lll}
G_{p p}+G_{p k} X_{p} & G_{p q}+G_{p k} K_{q} \\
G_{q p}+G_{q k} & K_{p} & G_{q q}+G_{q k} \\
K_{q}
\end{array}\right]\left[\begin{array}{l}
d p \\
d q
\end{array}\right]
$$

This breaks into two parts the longrun response to a price change: There is first an output change at given capital stocks, and there is in addition an output change due to the price-induced change in capital stocks. The difference between the shortrun and the longrun response is entirely due to the changed capital stocks.

PROPOSITION 3: If $\mathrm{I1}, \mathrm{T}$, I and $S$ apply, then the corxelation betreen a rector of final soods price changes and their ontput changes is greater in the longrun than it is in the shortrnn: That is

$$
d p^{\prime} d Y>d p^{\prime} d y \geq 0
$$

Proof: Put dq $=0$. Subtracting (17) from (19), and using (7) gives

$$
d p^{\prime}(d Y-d y)=-d p^{\prime} G_{p k} G_{k k}^{-1} G_{k p} d p>0
$$

by the negative definiteness of $G_{k k}$.

When a single price only goes up, according to this Proposition, the output of that final good expands in the longrun by more than it does in the shortrun. In the shortrun the output expands as more factors are drawn into the industry. There is an additional expansion in the longrun as the capital stock is adjusted to its appropriate configuration for the new prices. Hatters are more complex when a capital good increases in price. Such a price change increases the revenue from producing the capital good, and so raises its output in the shortrun. But the cost of capital is also increased, which dampens the incentive for capital formation. The balance of these opposing forces determines whether or not the longrun effect reinforces the shortrun effect on output. Before examining this, it is convenient to give some definitions and a preliminary resolt. 
DEFINITION 2: Capital good i is a gross complement to (substitute for) capital good if if and only if an increase in the stock of capital good i raises (lopers) the rental price of capital good $j$ : That is, $\partial x_{j} \angle \partial k, 0(<0)$, ifi.

Note that this definition of complementarity does not express an intrinsic froperty of capital goods. Rather, it rests on interconnections throughout the economy - it is a general equilibrium froperty, not a primitive concept about the system.

LEMMA: Suppose that a11 capital goods axe sxoss complementse. If I2 holds, then $G_{12}^{-1}$ is non-positive.

Proof: T2 implies that $G_{k k}$ is negative definite. If all capital goods are gross complements then the off-diagonal elements of $G_{k k}$ are all positive. A we11 known theorem on matrices then implies the result (see Takayama (1985, Theorem 4.D.3, p. 393)).

DEFINITION 3: Ner1y-prodnced capital good i is capjtg1-intensive if and only if $\partial x, \angle \partial z, 20, j=1, \ldots$.ente It is non-capital-intensire if and only if the opposite inegnalities hold.

This definition also expresses a general equilibrinm relationship. A similar definition applies to final goods. Neither for newly-produced capital goods, nor for final goods, are these categories exhaustive: There may be goods which are neither capital-intensive nor non-capital-intensive. 
PROPOSITION 4: If $T 1, T 2,0$ and $S$ apply, then there is a presumption that the correlation between a vector of changes in the prices of new ly-prodnced capital goods and the changes in their ontpots is greater in the longrun than it is in the shortrun: More precisely, $d g^{\prime} \cdot(d x-d x)$ consists of $a$ positive term and a term that may be of either sign. If only one price increases for a new ly-produced capital good, then its ontpot expands more in the longrun than it does in the shortrun if all capital goods are gross complements and if either (i) the capital good is noncapital-intensive or (ii) the capital sood is ' 'sufficient1y' capital intensive.

Proof: Put dp $=0$. Subtracting (17) from (19), and using (8) gives

$$
\begin{aligned}
d q^{\prime}(d X-d x)=-d q^{\prime} G & { }_{q k} G_{k k}^{-1} G_{k q} d q \\
& +d q^{\prime} G_{q k} G_{k k}^{-1} D(p+\delta) d q
\end{aligned}
$$

The first term on the right-hand side is positive, by the negativedefiniteness of $G_{k k}$. The second term may be of any sign.

If $d q_{1}=1, d q_{2}=\cdots \cdot=d q_{m}=0$, then (21) gives

$$
d x_{1}-d x_{1}=-G_{q_{1} k} G_{k k}^{-1}\left(G_{k q_{1}}-\Delta_{1}\right)
$$

where $G_{q_{1} k}$ is the first row of $G_{q k}, G_{k q_{1}}$ is the first column of $G_{k q}$ and $\Delta_{1}^{\prime}=\left(p+\delta_{1}, 0, \ldots, 0\right)$. The Lemma implies that $\mathrm{G}_{\mathrm{kk}}^{-1}$ is non-positive if all capjtal goods are gross complements. If the first capital good is non-capita1-intensive, then $G_{q_{1} k}\left(=G_{k q_{1}}\right)$ is negative. The sign of (22) is then clearly positive. This proves (i). On the other hand, if the first capjtal good is capital intensive, then $G_{q_{1} k}\left(=G_{k q_{1}^{\prime}}^{\prime}\right.$ is positive. Provided that 


$$
G_{q_{1} k_{1}}=\frac{\partial x_{1}}{\partial k_{1}}>\rho+\delta_{1}
$$

the sign in (22) is again posjtive. Thus ( $i j)$ is established.

The condition (23) may be witten as

$$
\frac{\partial r_{1}}{\partial q_{1}} \cdot \frac{q_{1}}{r_{1}}>1
$$

on using (3) and (6): That is, the elasticity of the rental price of the capital good with resfect to its output price exceeds unity. In this event, the increased price for the capital good will lead to a greater than froportional rise in its rental price. To achieve a steady state the capital good must be accumblated so that its marginal product is reduced. This accumation raises the rental prices of all of the complementary capital goods, and they must also be accumulated to reach equilibrium. These increased capital stocks permit even greater increases in output than occur in the shortrun.

Propositions 3 and 4 make an interesting contrast. The former provides a strong conclusion, which rests only on the most general features of the economy's structure. The latter, howerer, shows that to get any definite results about the effect on outputs of changes in capital goods prices it is necessary to make assumptions about the fine detail of inter-relationships in the economy. These assumptions may directly impose restrictions at the 1 evel of general equilibrium responses (as in Proposition 4), or they may impose restrictions at the more primitive level of the technology, in which case these restrictions must imply specific kinds of general equilibrium responses. It is, therefore, in the nature of the problem that no strong conclusions are available concerning the consequences of changes in capital goods prices. When the impact of output price changes on factor rewards are considered the outcome is similar. 
From (3),

$$
\left[\begin{array}{l}
d r \\
d w
\end{array}\right]=\left[\begin{array}{ll}
G_{k p} & G_{k q} \\
G_{v p} & G_{v q}
\end{array}\right]\left[\begin{array}{l}
d p \\
d q
\end{array}\right]
$$

gives the shortrun responses of factor rewards to ontput price changes. Using the longrun gross national froduct function, and (7) and (8), the longrun responses of factor rewards to output price changes is

$$
\left[\begin{array}{l}
d R \\
d W
\end{array}\right]=\left[\begin{array}{cc}
0 & D(p+\delta) \\
G_{v p}-G_{v k} \cdot G_{k k}^{-1} G_{k p} & G_{v q}-G_{v k} G_{k k}^{-1}\left(G_{k q}-D(p+d)\right)
\end{array}\right]\left[\begin{array}{l}
d p \\
d q
\end{array}\right]
$$

where $R$ and $\nabla$ respectively denote the steady state rental of capital goods and primary resource prices. Subtraction of (24) from (25) gives the djfference between the longrun and shortrun responses:

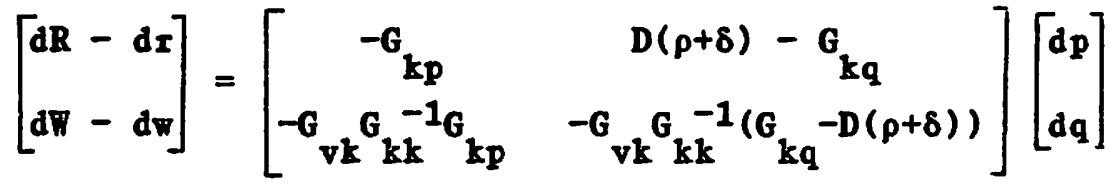

The only conclusions which do not depend on the detajls of the economy are (see (25)) that in the longrun the rates of return on capital are independent of the prices of final goods and are proportional to the prices of capital goods: These are, of course, obvious intuitively.

DEFINITION 4: Capital good i and primary resonce j a re complements

(substitntes) if and only if an increase in the endowment of the primary resonrce raises (10iers) the rental price of capita1: That is, $\partial x_{i} / \partial v j \geq 0(<0)$

An example is now given of the restricted kind of result that can be obtained. 
PROPOSITION 5: If T1, T2, O and S apply, then an increase in the exice of a final good $j 11$ in the longrun rajse by more lor lower by less) than it does in the shortrun the price of any primary resonrce if capital goods are complementary to primary resources, capital goods are gross complements and the final good is capital intensive.

Proof: Without loss of generality, let $d p_{1}=1, d p_{2}=. \cdot .=d p_{l}=0$, and consider the first primary resource. From (26)

$$
d W_{1}-d w_{1}=-G_{v_{1} k} G_{k k}^{-1_{G_{k}}}
$$

Since all capital goods are gross complements, by the Lemma $\mathrm{G}_{\mathrm{kk}}^{-1}$ is nonpositive. By definition, $G_{v_{1} k}$ is positive if capital goods are complementary to primary resources. Finally, $G_{1 p_{1}}$ is positive if the final good is capital intensive. Thus $d w_{1}-d w_{1}>0$.

This result is intuitive, of conrse. If the final good is capital intensive, an increase in its price vill raise capital stocks. This effect is accentuated by the complementarity of all capital goods. However, primary resonrces are also complementary to capital goods, so the price-induced increases in capital stocks raise the returns to the primary resources. Other results of the same kind are available from (27). For example, primary resource returns rise by less in the longrun than in the shortrun in response to an increased price for a final good if capital goods are substitutes for primary resonces, and otherwise the conditions of Proposition 5 apply. All of these results, however, rely on a detajled specification of the structure of the economy.

4. Shortrun and Longrun Responses to Changes in Primary Resource Endowmerts By differentiating (3) the shortrun responses of factor prices to changes in factor endowments can be calculated. 
PROPOSITION 6: If $T 2$ and $T 3$ apply, then there is a non-positive

correlation between the vectors of factor price

changes and factor endownent changes in the shortrun:

That is,

$$
\left[d k^{\prime} d v^{\prime}\right]\left[d x^{\prime} d w^{\prime}\right]^{\prime} \leq 0
$$

Proof: From (3)

Therefore

$$
\left[\begin{array}{l}
d x \\
d w
\end{array}\right]=\left[\begin{array}{cc}
G_{k k} & G_{k v} \\
G_{v k} & G_{v v}
\end{array}\right]\left[\begin{array}{l}
d k \\
d v
\end{array}\right]
$$

$$
\left[d k^{\prime} d v^{\prime}\right]\left[\begin{array}{l}
d x \\
d w
\end{array}\right]=\left[\begin{array}{ll}
d k^{\prime} & \left.d v^{\prime}\right]
\end{array}\left[\begin{array}{ll}
G_{k k} & G_{k v} \\
G_{v k} & G_{v v}
\end{array}\right]\left[\begin{array}{l}
d k \\
d v
\end{array}\right] \leq 0\right.
$$

since $T 2$ and $T 3$ imply that $G$ is concave in $k$, $v$, which implies that $\left[G_{i j}\right.$ ] is negative semi-definite.

This provides a benchmark against which longrun effects can be measured. Of course, in the longrun the capital stocks are endogenously determined, and the return on capital is independent of the endowments of primary resources (see (6)). There is, accordingly, no reason to consider any longrun effect except that of primary resource endowments on primary resource prices.

PROPOSITION 7: If T2, T3, U and S apply, then the correlation betreen a rector of changes in primary resonce endowments and their price changes is spallex in the longrun than it is in the shortrun: That is

$$
d v^{\prime} d w<d v^{\prime} d w
$$


Proof: From the longrun gross national product function

$$
d W=G_{v v} d v+G \underset{v k}{K} \mathbf{v} d v
$$

Putting dk $=0$ in (28), and subtracting this from $(30)$, gives

$$
d W-d w=-G_{\mathbf{v k}} \mathbf{G}_{\mathbf{k k}}^{-\mathbf{1}_{\mathbf{k}} \mathbf{G}} \mathbf{d v}
$$

on using (9). Hence

$$
d v^{\prime}[d W-d w]=-d v^{\prime} G_{v k} G_{k k}^{-1} G_{k v} d v>0
$$

since $G_{k k}$ is negative definite.

Whereas an increased endowment of primary resources tends to 10 er their prices in the shortrun, this effect is mitigated in the longrun by the induced accumulation of capital. Propositions 3 and 7 are alike: They each give general and unequivocal results about the longrun and shortrun relationship of quantities and prices of particular kinds of commodities. Other results rest on stronger assumptions, however,

DEFINITION 5: Final good $i$ is intensive in the nse of primary resonce $j$ if and only if $\partial \mathrm{v} / \partial p_{j}>0$. If the opposite inequality holds the good is non-intensive in the resonxce.

A similar definition holds for newly-produced capital goods. Note that Definitions 2-5 exhanst the combinations of goods and factors that can be related.

PROPOSITION 8: Snppose that T1 holdse An increase in the endorment of a primaxy resonxce wi11, in the shortrnn, resplt in elther an increase on average of the ontpat of those goods nsing the factor intensively or a decrease on ayerage of the ontput of those goods nsing the factor non-intensively. More Beneraj17e 


$$
d v^{\prime}\left[\begin{array}{lll}
G_{p p} & G_{v q}
\end{array}\right]\left[\begin{array}{l}
d y \\
d x
\end{array}\right] \geq 0
$$

Proof: From (2)

$$
\left[\begin{array}{l}
d y \\
d x
\end{array}\right]=\left[\begin{array}{c}
G \\
g v \\
G \\
q v
\end{array}\right] d v
$$

Therefore

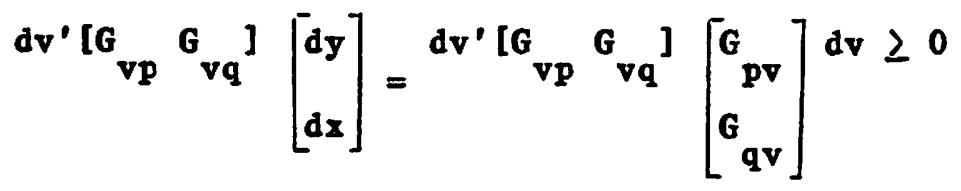

Suppose that $d v_{1}=1, d v_{2}=\ldots . .=d v_{n}=0$. Recal1 that

$$
G_{1_{p_{i}}}=\frac{\partial w_{1}}{\partial p_{i}}, G_{1_{q_{i}}}=\frac{\partial w_{1}}{\partial q_{i}}
$$

Then (34) implies that

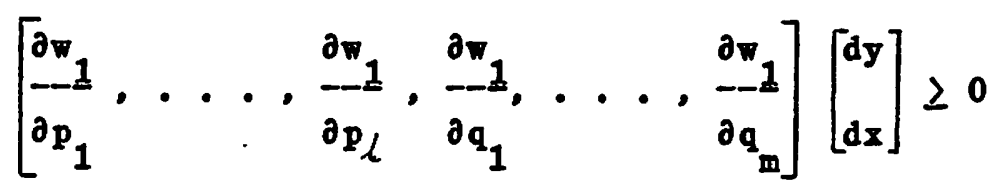

At least one output most expand becanse of the increased availability of the f'jrst primary resonrce. For the inequality to hold, either the expanded output must be in an industry which ases intensively the primary resource, or the output must fall on average in those industries which use the resource non-intensive1y.

This proposition is a generalized Rybczynski theorem. It does not rely on constant-returns-to scale, however.

A change in primary factor endowments will alter in the shortrun the 
rates of return on capital. Whether capital goods are substitutes for or complements to primary resources will determine the direction of this alteration: See (28). The longrun adjustment in capital stocks depends on the relationship between factors, therefore.

The longrun gross national product functjon yjelds

$$
\left[\begin{array}{l}
d Y \\
d X
\end{array}\right]=\left[\begin{array}{l}
G \\
G_{p v}+G_{p k} R \\
G_{q v}+G_{q k} K_{v}
\end{array}\right] d v
$$

as the longrun output effect of a change in primary resource endowments. Subtracting (33) from (36) and using (9) gives

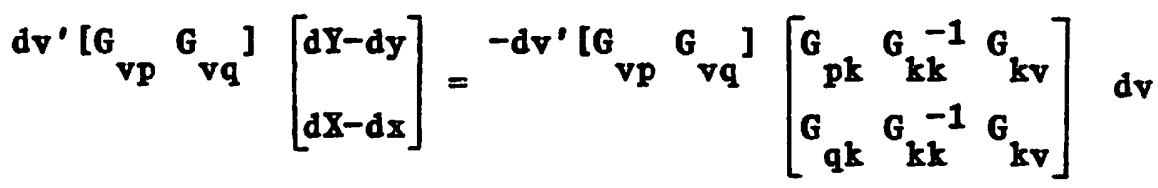

The sign of (37) is, in general, ambignons.

PROPOSITION 9: Suppose that T1, I2, T3, I and S applye An increase in the endoment of a primary resonrce rill have less effect on ontput on arerage in the longrnn than in the shortran if a11 capital soods are sross complementse capital goods axe complenentary te pximatr resonxcese and if every sood is either intensive in the nse of capital and non-intensive in the nse of the primgry resonce, or is non-intensive in the nse of capital and intensive in the nse of the primary resonrce.

Proof: Without loss of generality, let $d v_{1}=1, d v_{2}=\ldots=d v_{n}=0$. Then the right-hand side of (37) becomes

$$
-\left[\begin{array}{ll}
G_{v_{1} p} & G_{v_{1} q}
\end{array}\right]\left\lceil\left[\begin{array}{l}
G_{p k} \\
G_{-2}
\end{array}\right\rceil G_{k k}^{-1} G_{k v_{1}}<0\right.
$$


The inequality follows from the assumptions that capital goods are gross complements (the Lemma skows that $\mathrm{Gk}_{\mathrm{kk}}^{-1}$ is non-positive), that cafital and primary resources are complementary (so that $G_{\mathbf{k v}_{1}}$ is positive), and the intensity assumptions (so that $G_{v_{1} p}$ and $G_{v_{1} q}$ are of opposite sign to $G_{p k}$ and Gk' resfective1y).

Consider the second alternative. In the shortrun an addition to the stock of a primary resource will rajse the return on the complementary factors, the capital stocks, and expand the output of those goods which are intensive in the use of the primary resource. Now, the higher return on capital signals an expansion in the stock of capital. However, those goods which are intensive in the primary resource are non-intensive in capital, so their outputs decline, which offsets the shortrun output expansion. A similar explanation can be developed for the first alternative.

\section{Time Preference and the Steady State.}

The rate of time preference has no influence in the shortrun. Its longrun effects operate through the steady-state capital stocks. PROPOSITION 10: An increase in time preference reduces at least one capital stock in the steady state, and reduces the total yalue of capital stocks at any set of prices.

Proof: Using (10), since $G_{k k}^{-1}$ is negative definite,

$$
q^{\prime} K_{p}=q^{\prime} G_{k k}^{-1} q<0
$$

That is, the total value of capital stocks falls as time preference rises. Since all prices are positive, at least one derivative in $K_{p}$ is negative.

The second part of this proposition is explicitly stated by Woodland (1982, p. 481), and the first part is almost given there too.

The value of consumption in any steady state equals net national product, which is given by the function

$$
N(p, q, k, v)=G(p, q, k, v)-q^{\prime} D(\delta) k
$$


PROPOSITION 11: Net national product is maximized in the steady state when the rental price of each capital sood equals the depreciation on its price: That is$$
\mathbf{I}=\mathbf{D}(\boldsymbol{\delta}) \mathbf{q} \text {. }
$$

An increase in time preference reduces the value of steagr-state consumption.

Proof: Recall that $G_{k}=r$. The first-order condition for the maximum of (40) with respect to $k$ is $(41)$. Now

$$
N_{p}=G_{k} K_{p}-q^{\prime} D(\delta) K_{p}
$$

Substitution of (6) and (10) gives

$$
N_{p}=q^{\prime} D(p) G_{1 k k}^{-1} q<0
$$

The first of these results is a general version of the familiar golden-rule of economic growth. Its derivation is straightforward, despite the possibility of joint products and arbitrary numbers of consumption and capital goods. That increases in time preference reduce net national product is also well known, but it is established here in a particularly simple fashion.

6. Taxes.

The model presented in Section 2, and analyzed in Sections 3, 4 and 5 , can be interpreted as concerning either optimal or equilibrinm growth. By inserting taxes into the model attention is focused on the second interpretation.

In the presence of taxes a distinction mast be drawn between the prices received by sellers and the prices paid by buyers. Thus,

$$
p_{c}=p_{s}+\theta_{p} ; q_{c}=q_{s}+\theta_{q} ; r_{s}=r_{c}+\theta_{r}
$$

Here, $p_{c}$ is the price paid for final goods by consumers, which equals the price that producers receive, $p_{s}$, plus the specifjc taxes $\theta_{p}$. All factors 
are owned by consumers, so what they pay for capital goods, $q_{c}$, must equal what producers receive, $q_{c}$, plus taxes $\theta_{q}$. Finally, the rental price that firms pay for capital, $I_{s}$, is made of of the rental to the factor owners, $r_{c}$ and the $\operatorname{tares} \theta_{r}$. Firms and consumers are motivated by the (different) prices that confront them. Definition 1 mast be modified accordingly. DEFINITION 6: The gross national prodnct function (at producer prices) is given by

$$
G\left(p_{s}, q_{s}, k, v\right)=\frac{\text { Maximum }}{y, x}\left\{p_{s}^{\prime} y^{+}+q_{s}^{\prime} \cdot x: T(y, x, k, v)=0\right\}
$$

This enjoys most of those properties previously noted for the gross national product function, except that with taxes

and

$$
y=G_{p_{s}} \text { and } z=G_{q_{s}}
$$

$$
r_{s}=G_{k} \text { and } w=G_{v}
$$

take the place of (2) and (3).

The consumers' problem is to maximize utility subject to (1), (5) and the budget constraint, which becomes instead of (4)

$$
p_{c}^{\prime} c+q_{c}^{\prime} s=p_{c}^{\prime} y+q_{c}^{\prime} x
$$

This implicitly assumes that all tax revenues are returned to consumers. It can be shown that in the steady state

$$
G_{k}\left(p_{c}-\theta_{p}, q_{c}-\theta_{q}, k, v\right)-\theta_{r}=D(p+\delta) q_{c}
$$

which compares with (6). This implicitly defines the steady-state capital stocks as a function $X\left(p_{c}-\theta_{p^{\prime}} q_{c}-\theta_{q^{\prime}} \theta_{r^{\prime}} v, p\right)$. C1early,

$$
\begin{aligned}
& -\mathbf{K}_{\mathbf{p}_{\mathbf{c}}}=\mathbf{B}_{\boldsymbol{\theta}_{\mathbf{p}}}=\mathbf{G}_{\mathbf{k k}}^{-\mathbf{1}_{\mathbf{G}_{\mathbf{k p}}}} \\
& \mathrm{K}_{\boldsymbol{\theta}_{\mathrm{q}}}=\mathbf{G}_{\mathrm{kk}}^{-\mathbf{1}_{\mathbf{G}_{\mathrm{kq}}}} \\
& \mathbf{B}_{\theta_{I}}=\mathbf{G}_{\mathbf{k k}}^{-1}
\end{aligned}
$$

For given prices to consumers, (42) implies that 


$$
d p_{s}=-d \theta_{p} \text { and } d q_{s}=-d \theta_{q}
$$

That is, an increase in a tax on final or newly-produced capital goods sales is equivalent to a reduction in the price received by their producer. As a corollary of Profosition 2 the following result is immediate.

PROPOSITION 12: If T1 appliese there is a non-positive correlation between the rector of tax changes on fingl or newly-prodnced capital goods and the rector of their ontput changes in the shortrnn: That is

$$
d \theta_{p}^{\prime} d y<0 \text { and } d \theta^{\prime} \cdot d x<0
$$

The shortrun effects of the tar change are derived directly from the shortrun effects of a price change. However, in the longrnn the effect of a tax increase is not simply the opposite of the effect of a price increase. Indeed, it turns out that a definite conclusion can be reached about the steady-state effect of an increased tax on newly-produced capital goods, in contrast to the ambignity associated with an increase in their price.

PROPOSITON 13: If $T 1, T 2$, D and $S$ apply, then the correlation betreen a rector of taxes on fingl or nevly-produced capital goods and theif ontput changes is more negative (that is, greater in absolute value) in the longran than it is in the shortxun: That is

$$
\underset{p}{\left[d \theta^{\prime} d \theta^{\prime}\right]}\left[\begin{array}{l}
d Y \\
d X
\end{array}\right]<\underset{p}{\left[d \theta^{\prime} d \theta^{\prime}\right]}\left[\begin{array}{l}
d y \\
d x
\end{array}\right] \leq 0
$$

Proof: From the longrun gross national product function with taxes 


$$
\left[\begin{array}{l}
d Y \\
d X
\end{array}\right]=-\left[\begin{array}{l}
G_{p_{s} p_{s}}+G_{p_{s} k} K_{\theta_{p}} G_{p_{s} q_{s}}+G_{p_{s} k}{ }^{\theta_{\theta_{q}}} \\
G_{q_{s} p_{s}}+G_{q_{s} k}{ }_{\theta_{p}} G_{q_{s} q_{s}}+G_{q_{s} k} K_{\theta_{q}}
\end{array}\right]\left[\begin{array}{l}
d \theta_{F} \\
d \theta_{q}
\end{array}\right]
$$

On subtracting (51) frow (52), and using (47) and (48),

$$
\begin{aligned}
& \left.\underset{p}{\left[d \theta^{\prime}\right.} d \theta^{\prime}\right]\left[\begin{array}{l}
d Y-d y \\
d X-d x
\end{array}\right]
\end{aligned}
$$

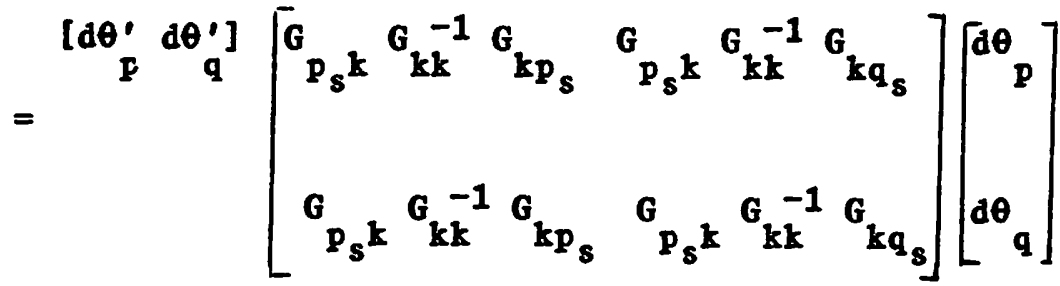

by the negative definiteness of $G_{k k}^{-1}$.

Of course, the reason why this definite conclusion is reached about the longrun impact of capital taxes is that prices to consumers are held constant. This eliminates any impact by the tax on consumers' desired holdings of capital.

No impact is felt in the shortrun from a change in the tax on capital earnings, $\theta_{I}$. In the longrun, (46) implies that the return to consumers on capital is constant when the prices they face for capital goods are fired. An increase in the taxes on capitals' earnings therefore affects the longrun equilibrium through its effects on the profitability of production. PROPOSITION 14: If T1, T2, $D$ and $S$ apply, then there is a negative correlation between a vector of changes in taxes on the earnings of capital and the vector of capital stocks: That is

$$
d \theta^{\prime} \mathrm{dk}<0
$$

In particular, an increased tax on the earnings of a 
If, in addition, all capital goods are gross complementse an increase in taxes on the earnings of carital wi11

lead to a decrease (increase) in the ontrot of capitalintensive (non-capita1-intensive) soods.

Proof: From (49)

$$
d \theta^{\prime} d \mathbf{k}=d \theta_{I}^{\prime} G_{\mathbf{k}}^{-1} d \theta_{I}<0
$$

since $G_{k k}^{-1}$ is negative definite. If $d \theta_{I_{1}}=1, d \theta_{I_{2}}=\ldots .=d \theta_{I_{m}}=0$, then (53) implies that $d k_{1}<0$. Of course

$$
\left[\begin{array}{l}
d Y \\
d X
\end{array}\right]=\left[\begin{array}{l}
G_{P_{s}} k \\
G_{q_{s}} k
\end{array}\right] G_{k t}^{-1} d \theta_{I}
$$

If all capital goods are gross complements, the Lemme shows that $G_{k k}^{-1}$ is non-positive. The ith row of $G_{p_{s}}$ is positive if and only if the ith $f$ inal good is capital intensive. But then $d Y_{i}$ is negative when $d \theta_{I}>0$. The other cases are simjlar.

In the absence of taxes the present value of the flow of utility is maximized. Taxes reduce this present value, and alter the flow of utility. The extent of this alteration can be derived from the expenditure function $E\left(p_{c}, u\right)$. This gives the minimum expenditure necessary at consumer prices $p_{c}$ to attain the utility level $\mathrm{n}$. Onder the smal1-contry assumption consumer prices equal world market prices if there are no trade tares. In the steady state the value of gross investment equals the value of the depreciation of capital stocks, so that

$$
E\left(p_{c}, z\right)=p_{c}^{\prime} y+q_{c}^{\prime} x-q_{c}^{\prime} D(\delta) k
$$

Using (42) and Definition 6, this can be written as

$$
E\left(p_{c}, u\right)=G\left(p_{s}, q_{s}, k, v\right)+\theta_{p}^{\prime},+\theta_{q}^{\prime} D(\delta) k
$$

where $k$ is defined by (46). To discrss the effect of tares on the steadystate flow of utility the following definitions are useful. 
DEFINITION 7: Taxes on final goods are rroportional if and only if

$$
\phi_{p}=\frac{{ }_{\boldsymbol{F}_{\mathbf{p}}}}{\mathrm{P}_{c_{i}}}, j=1, \ldots, l
$$

Taxes on capital boods are proportional if and only if

$$
\phi=\frac{\theta_{q_{i}}}{q_{c_{i}}}, i=1, \ldots, m
$$

Commodity taxes axe proportional if and only if

$$
\phi_{\mathbf{p}}=\phi_{\mathbf{q}}
$$

Taxes on the earnings of capital are proportional if and

only if

$$
\phi_{I}=\frac{\theta_{I}}{I_{i}}, i=1, \ldots, m
$$

PROPOSITION 15: If commodity taxes are proportionale then a tax increase has ne effect on the shortrun equilibrium. If hovever, depreciation rates are similare then ntility is reduced in the steady state. This also occurs if time ereference is zero, or close to it.

Proof: Differentiation of (54) implies that

$$
E_{u} \cdot d u=q_{c}^{\prime} D(p) G_{k k}^{-1}\left[G_{k p_{s}} \quad G_{k q_{s}}\right]\left[\begin{array}{c}
d \theta_{p} \\
d \theta_{q}
\end{array}\right]
$$

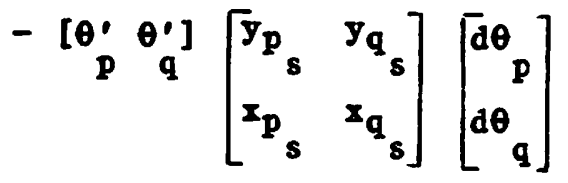

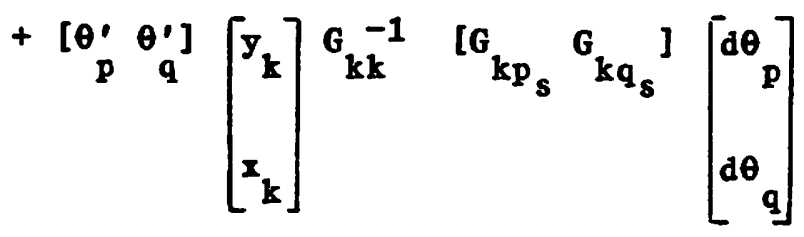


where (43), (44) and (46) have been nsed.

The second term in (55) is zero for the tax increase considered here. This is a consequence of the fact that ontputs are homogeneous of degree zero in producer frices. Now (42) and the definition of proportional commodity taxes imply that

$$
d \theta_{p}=p_{s} d \phi(1+\phi) \text { and } d \theta_{q}=q_{s} d \phi(1+\phi)
$$

where $\phi=\phi_{p}=\phi_{q}$ and $d \phi$ is the common rate at which commodity taxes are increased. Substituting (56), and using Euler's theorem, yields the conclusion that the second term of (55) is zero. Since the other terms in (55) involve changes in the capital stock this also establishes the shortrun neutrality of the tax changes.

Recall that $y_{k}=G_{p_{s}}$ and $x_{k}=G_{q_{s}} \cdot$ The third term of (55) is then

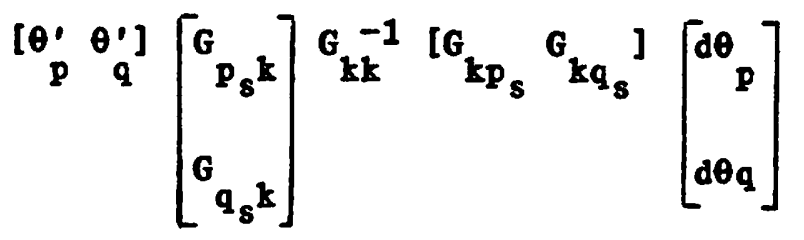

But the definition of proportional taxes implies that

$$
d \theta_{p}=\theta_{p} d \phi / \phi, d \theta_{q}=\theta_{q} d \phi / \phi
$$

Substitution of (58). into (57) reveals that term to be negative, in viev of the negative definiteness of $G_{k k}^{-1}$.

Finally, consider the first term of (55). Recall that $G_{k p_{s}}=\left[\partial_{i} / \partial p_{s_{j}}\right]$ and $G_{k q_{s}}=\left[\partial r_{i} / \partial q_{s_{j}}\right]$. If all producer prices rise in the same proportion then so do the value marginal products of all capital goods $r$ ise in the same proportion. The rows of $\left[\mathrm{G}_{\mathrm{kp}} \mathrm{G}_{\mathrm{kq}_{s}}\right.$ ] are, therefore, homogeneous of degree one in prices. Together with (56), this fact permits the first term of (55) to be witten as

$$
\begin{aligned}
& q_{c}^{\prime} D(\rho) G_{k k}^{-1} r_{s} d \phi /(1+\phi) \\
& \quad=q_{c}^{\prime} D(\rho) G_{k k}^{-1} D(\rho+\delta) q_{c} d \phi /(1+\phi)
\end{aligned}
$$

where the steady-state equilibrinm condition (46) has been used to eliminate 
$I_{s}$. This is negative if $\delta_{1}=\ldots=\delta_{m}$. By continuity, it is al so negative if the depreciation rates are sufficiently close together.

If depreciation rates are close, (55) is negative, since the first and third terms are negative and the second is zero.

If the rate of time preference is zero then (59) is zero. For small enough $\rho$, by continuity, (59) is close to zero. If positive it will be outweighed by the unambiguously negative third term.

There is a presumption that taxes will lower the flow of otility in the steady state. This certainly occurs in the absence of time preference. Yet it is possible that taxes raise the steady state flow of utility. For this to happen the first term in (55) must be positive enough to offset the negative third term.

Proposition 15 gives a result about proportional taxes on all goods. A result is also avajable concerning the effect of a proportional tax on a subset of goods.

PROPOSITION 16: If time preference is zero, or close to it then the imposition of a proportional tax on final soods lor on capital goods) rednces the flor of ntility in a steady state.

Proof: Consider a proportional tar on final goods. Then $\theta_{q}=d \theta_{q}=0$. The second term of (55) is just

$$
\theta_{p} y_{p} d \theta_{p} \leq 0
$$

on using (56) and the negative semi-definiteness of the matrix.

The third term of (55) is negative, as in the Proof of Proposition 14.

The first term of (55) is zero if $p=0$, and is close to zero for small $p$. It can, therefore, be outweighed by the other two negative terms. Fina11y, the effect of a tax on capjtal can be discovered. 
PROPOSITION 17: If depreciation rates are similare or if the rate of time preference is zero (or close to it) then a prorortional tax on capital earnings ril1 reduce the flor of ntility if the steady state when compodity taxes axe proportional (or zero).

Proof: Differentiation of (54) implies that

$$
\begin{aligned}
E_{v} d u & =q_{c}^{\prime} D(p) G_{k k}^{-1} d \theta_{I}+\theta_{I k k}^{\prime} G_{I}^{-1} d \theta_{I} \\
& +\left[\theta_{p}^{\prime} \underset{q}{\left.\theta^{\prime}\right]}\left[\begin{array}{l}
y_{k} \\
x_{k}
\end{array}\right] G_{k k}^{-1} d \theta_{I}\right.
\end{aligned}
$$

Where (46) and (49) have been used.

Using the definition of proportional taxes on capital earnings, the second term of $(60)$ is

$$
\theta_{\mathbf{I}}^{\circ} \mathrm{kk}^{-1} \mathrm{~d} \theta_{\mathrm{I}} \mathrm{d} \phi_{\mathrm{I}} / \phi \mathbf{I}<0
$$

The first term of $(60)$ is

$$
q_{C}^{\prime} D(p) G_{k k}^{-1} D(p+\delta) q_{C} d \phi_{T}
$$

where (42), (46) and the definition of proportional tares have been used. If $\delta_{1}=\ldots=\delta_{m}$ then this is negative. So is it for depreciation rates that are similar. It is zero if $p=0$, and is small for small $p$.

Consider now the third term of $(60)$. It is zero if commodity tares are zero (and hence proportional). Otherwise, note that

$$
\left[\begin{array}{ll}
\theta_{p}^{\prime} & \left.\theta_{q}^{\prime}\right]
\end{array}\left[\begin{array}{l}
y_{k} \\
x_{k}
\end{array}\right]=\underset{1-\phi}{-1}\left[\begin{array}{ll}
p_{s}^{\prime} & \left.q_{s}^{\prime}\right]
\end{array}\left[\begin{array}{l}
y_{k} \\
x_{k}
\end{array}\right]=G_{k}^{\prime} /(1-\phi)\right.\right.
$$

using again the definition of proportional tares with $\phi=\phi_{p}=\phi_{q}$, and recalling the definition of the gross national product function. But $G_{k}=$ 
$r_{s}$. The third term of $(60)$ is therefore

$$
r_{s}^{\prime} d z /(1-\phi)=d \theta_{r}^{\prime} d k\left(1+\phi_{r}\right) / \phi d \phi r<0
$$

where Proposition 14 gives the inequality.

In the absence of time preference the flow of utility is maximized in the steady state. Any tax or subsidy on capital earnings will reduce this flow. If, however, time preference is positive, then a proportional subsidy on capital earnings may raise the flow of utility: But this is guaranteed only if depreciation rates are similar.

\section{Concluding Remarks}

The advantages of the dual approach to static analysis are well known. This paper has shown that there are similar advantages when the technique is osed in dynamic, steady-state, analysis. Where general results are available, they are derived quite simply from the longrun gross national product function. There general results are not available, it is made clear what kinds of structural assumptions are needed to obtain particular results. In both situations average relationships are established, not precise 1 inks from parameters to endogenous variables. Hovever, average relationships are the more useful in empirical tests of theory. 


\section{Footnotes}

1. It seems intuitive that it is optimal to arbitrage away longron cycles. This intuition is incorrect, however, as an example from a different contert makes clear. Gallagher and Manning (1982) considered water storage, and showed that it is not worthwile to eliminate cycles, even if it is technically possible to do so. Suppose that the price of water follows a seasonal pattern. As long as there is a positive rate of interest (or time Freference) it is not profitable to arbitrage away all price differences, even if there are no costs of water storage. In fact, while water is held in storage its price must go np at the rate of interest. The price then falls when the storage facility is emptr, and a new cycle begins. (This provides an extension of Hotelling's rule to cyclically available resources.)

2. Column vectors are considered throughout.

3. Both $c$ and $s$, as we11 as $y$ and $x$, are functions of time. But it is convenient (and appropriate in steady-state analysis) to ignore this argument.

4. Furthermore, $G_{k k}$ is negative definite, as is $G_{k k}^{-1}$, under the assumption of non-singularity, since $G$ is strictly concave in capital stocks. This assumption is maintained throughout. 
References

Acheson, K. (1970). The aggregation of heterogeneous capital goods and various trade theorems, Journal of Political Economp 78 : 565-71.

Benhabib, J. and R. Nishimura (1979), The Hopf bifurcation and the existence and stability of closed orbits in multisector models of optimal economic growth, Jonxnal of Economic Theory 21: 421-44.

Brace, N. (1977), The effects of trade taxes in a two-sector model of cafital accumiation, Journal of International Economics 7: 283-94.

Dixit, A. and V. Norman (1980), Theorr of International Trade: A Daral, General Equilibrium Approach, Melwyn; Nisbet.

Ethier, M. (1979), The theorems of international trade in time-phased economies, Journal of International Economics 9: 225-38.

Feldstein, M. (1974a), Incidence of a capital income tax in a growing economy with variable savings rates, Reviev of Economic Studjes 41: 505-13.

Feldstein, M. (1974b), Tax incidence in a growing economy with variable factor supply, Quarterly Journal of Economics 88: 551-73.

Gallagher, D, and R. Manning (1982), Optimal water pricing and storage: The effect of discounting. Hater Resonxces Research 18: 65-70.

Inada, K. (1968), Free trade, capital accumulation and factor-price equalization, Economic Record 44: 322-41.

Johnson, H.G. (1971), Trade and growth: A geometrical exposition, Journal of Internstional Economics 1: 83-101.

Kemp. M.C. and C. Khang (1974), A note on steady-state price-ontput relationships, Journa1 of International Economics 2: 187-97.

Long. N.V. (1973), On a paradoz in the theory of international capital movements, Economic Record 41: 440-6.

Manning R. (1975), Attitudes to international capital movements in the longrun: The case with neoclassical savings in the foreign contry, Economic Recerd 51: 242-8.

Hanning, R. (1982), Trade, education and growth: The sma11-conntry case, International Economic Revier 23: 83-106.

Markusen, J.R. and L. Svensson (1985), Trade in goods and factors with international differences in technology. International Economic Reviev 26: 175-92.

KcKenzie, L.W. (1976), Turnpike theory, Econometrica 44: 841-65. 
Neary, J.P. (1985), International factor mobility, minimum wage rates, and factor-price equalization: A syothesis, Qugrterly Jonrngl of Economics 100: 551-70.

Neary, J.P. and F. Ruane (1985). International cafital mobility, shadow prices, and the cost of frotection, Centre for Economic Policy Research.

Negishj, T. (1965) Foreign investment and the longrun national advantage, Economic Record 41: 628-32.

Oniki, B, and H. Uzawa (1965), Patterns of trade and investment in a dynamic model of international trade, Revier of Economic Studies 32: 15-34.

Petith, H.C. (1976). The Stolper-Samuelson theorem, the Rybczynski theorem, and the pattern of trade in neo-classical and vintage capital trade and growth mode1s, International Economic Revier 17: 57-75.

Ruffin, R. (1979), Growth and the longrun theory of international capital movements, American Economic Rerier 69: 832-42.

Ruffin, R. (1985). Taxing international capital movements in a groring vor1d, Jonrnal of International Economics 18: 261-80.

Samnelson, P.A. (1975), Trade pattern reversals in time-phased Ricardian systems and intertemporal efficiency. Jonrnal of International Economics 5: 309-63.

Stiglitz, J.E. (1970), Factor price equalization in a dynamic economy, Jonsnal of Political Economy 78 : 456-88.

Takayama, A. (1985), Mathematica1 Economics (2nd edition) Cambridge University Presss New York.

Woodland, A.D. (1982), Internationgl Irade and Resonxce Allocation, NorthHo11and; Amsterdam. 
8601C Greenwood, Jeremy and R. Preston licAfee. EXTERNALITIES AND ASYMMETRIC INFORMATION.

8602C Dinopoulos, Elias and Mordechai E. Kreinin. IMPORT QUOTAS AND VERS: A COMPARATIVE ANALYSIS IN A THREE-COUNTRY FRAMEWORK.

8603C Clarete, Ramon and John whalley. COMPARING THE MARGINAL WELFARE COSTS OF COMMODITY AND TRADE TAXES.

8604C Wigle, Randall. CANADIAN TRADE LIBEPALIZATION: SCALE ECONOMIES IN A GLOBAL CONTEXT.

8605C Parkin, Michael. DOMESTIC MONETARY INSTITUTIONS AND FISCAL DEFICITS.

8606C Dinopoulos, Elias and Ian Wooton. INTERNATIONAL TRADE AND THE ACQUISITION OF SKILIS.

8607C Kawasaki, Seiichi and John McMillan. THE DESIGN OF CONTRACTS: EVIDENCE FROM JAPANESE SUBCONTRACTING.

8608C Williamson, Stephen D. IIQUIDITY, BANKING, AND BANK FAILURES.

8609C Grossman, Gene M. and Carl Shapiro. COUNiERFEIT-PRODUCT TRADE.

8610C Deardorff, Alan V. WHY DO GOVERNMENTS PPEFER NONTARIFF BARRIERS?

$8611 C$ Horstmann, Ignatius and James R. Markusen. LICENSING VERSUS DIRECT INVESTMENT: A NODEL OF INTERNALIZATION BY THE MULTINATIONAL ENTERPRISE.

8612C Thursby, JeryY G. and Marie C. Thursby. BILATERAT TRADE FLOWS, THE LINDER HYPOTHESIS, AND EXCHANGE RISK.

8613C Clarete, Ramon and John Whaliey. EQUILIBRIUM IN THE PRESENCE OF FOREIGN EXCHANGE RREMIA.

8614C Wooton, Ian. TOWARDS A COMMON MARKET: FACTOR MOBII.ITY IN A CUSTOMS UNION.

8615C St-hilaire, France and John Whalley. SOME ESTIMATES OF TRADE FLOWS IN BANKING SERVICES.

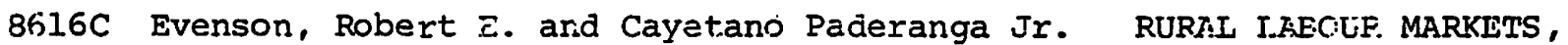
TEANSACTION COST END FET:TILITY.

8617C Fried, Joel and Peter Howitt. FISCAL DEFICITS, INTERNATIONAL TRADE AND WELFARE.

8618C Trela, Irene, John Whalley and Randall Wigle. INTERNATIONAL TRADE IN AGRICULTURE: DOMESTIC POLICIES, TRADE CONFLICTS, AND NEGOTIATING OPTIONS.

8619C Markusen, James R. and Anthony J. Venables. TRADE POLICY WITH INCREASING RETURNS AND IMPERFECT COMPETITION: CONTRADICTORY RESULTS FROM COMPETING ASSUMPTIONS .

$8620 \mathrm{C}$ Hunter, Linda and James R. Markusen. PER-CAPITA INCOME AS A DETERMINANT OF TRADE.

8621C Jones, Rich and John whalley. A CANADIAN REGIONAL GENERAL EQUILIBRIUM MODEL AND SOME APPLICATIONS.

8622C Freeman, Scott and Gregory W. Huffman. INSIDE MONEY, OUTPUT, AND CAUSALITY.

$8623 \mathrm{C}$ Hamilton, Colleen and John Whalley. DEALING WITH THE NORTH: DEVELOPING COUNTRIES AND GLOBAL TRADE NEGOTIATIONS.

8624C Williamson, Stephen D. LAISSEZ FAIRE BANKING AND CIRCULATING MEDIA OF EXCHANGE.

8625C Whalley, John. WHAT HAVE WE LEARNED FROM GENERAL EOUILIBRIUM TAX POLICY MODELS? 
8626C Bhatia, Kul B. SHORT RUN AND LONG RUN IN THE THEORY OF TAX INCIDENCE.

8627C Jones, Rich and John Whalley. REGIONAL EFFECTS OF TAXES IN CANADA: AN APPLIED GENERAL EQUILIBRIUM APPROACH.

8628C Nguyen, Trien T. and John Whalley. GENERAL EQUILBRIUM WORLD TRADE UNDER BILATERAL QUOTAS.

8629C Clarete, Ramon $L$ and James A. Roumasset. THE RELATIVE COST OF INDUSTRIAL AND AGRICULTURAL PROTECTION POLICIES USING PHILIPPINE DATA.

\section{$\underline{1987}$}

8701C MCMillan, John, John Whalley and zhu Lijing. INCENTIVE EFFECTS OF PRICE RISES AND PAYMENT-SYSTEM CHANGES OF CHINESE AGRICULTURAL PRODUCTIVITY GROWTH.

8702C Wooton, Ian. CAPITAL, SKILLS, AND INTERNATIONAL TRADE.

8703C RYan, Cillian. TRADE IN THE PRESENCE OF ENDOGENOUS INTERMEDIATION IN AN ASYMMETRIC WORLD.

8704C Kennan, John and Raymond Riezman. OPTIMAL TARIFF EQUILIBRIA WITH CUSTOMS UIIIONS.

8705C Feenstra, Robert C. and Tracy R. Lewis. NEGOTIATED TRADE RESTRICTIONS WITH PRIVATE POLITICAL PRESSURE.

8706C Brecher, Richard A. POLICY-INDUCED INFLOWS OF FOREIGN CAPITAL IN THE PRESENCE OF RIGID-WAGE UNEMPLOYMENT.

8707C Harrison, Glenn W., Richard Jones, Larry J. Kimbell, and Randall Wigle. HOW ROBUST IS APPLIED GENERAL EQUILIBRIUM ANALYSIS?

8708C Jones, Richard and John Whalley. REGIONAL BALANCE SHEETS OF GAINS AND LOSSES FROM NATIONAL POLICIES.

8709C Markusen, James R. TRADE IN PRODUCER SERVICES AND IN OTHER SPECIALIZED INTERMEDIATE INPUTS.

$8710 \mathrm{C}$ Markusen, James R. PRODUCTION, TRADE AND MIGRATION WITH DIFFERENTIATED, SKILLED WORKERS.

$8711 C$ Markusen, James R. INTRA-FIRM SERVICE TRADE BY THE MULTINATIONAL ENTERPRISE.

8712C Parkin, Michael. MONETARY POLICY AND AGGREGATE FLUCTUATIONS.

$8713 \mathrm{C}$ Smith, Bruce D. LEGAL RESTRICTIONS, "SUNSPOTS", AND CYCLES.

8714C Harrison, Glenn W. and E.E. Rutstrom. TRADE WARS AND TRADE NEGOTIATIONS: A COMPUTATIONAL APPROACH.

8715C Smith, Bruce D. MONEY AND INFLATION IN THE AMERICAN COLONIES: FURTHER EVIDENCE ON THE FAILURE OF THE QUANTITY THEORY.

8716C Wonnacott, Paul and R.J. Wonnacott. UNILATERAL FREE TRADE VS. A CUSTOM's UNION: THE FURTHER SEARCH FOR A GENERAL PRINCIPLE.

$8717 \mathrm{C}$ NearY, Peter. TARIFFS, QUOTAS AND VOLUNTARY EXPORT RESTRAINTS WITH AND WITHOUT INTERNATIONALLY MOBILE CAPITAL.

$8718 \mathrm{C}$ Schmitt, Nicolas. TWO-COUNTRY TRADE LIBERALIZATION IN AN ADDRESS MODEL OF PRODUCT DIFFERENTIATION.

871.9C Greenwood, Jeremy and Gregory W. Huffman. ON MODELLING THE NATURAL RATE OF UNEMPLOYMENT WITH INDIVISIBLE LABOR. 
8801C Bhatia, Kul B. FOREIGN TRADE AND INCOME DISTRIBUTION: THE CASE OF MALAYSIA.

8802C Greenwood, Jeremy, Zvi Hercowitz, and Gregory w. Huffman. INVESTMENT, CAPACITY UTILIZATION AND THE REAL BUSINESS CYCLE.

8803C Kymlicka, B.B., John Whalley, and Ronald J. Wonnacott. THE CANADA-US FREE TRADE AGREEMENT: REACTIONS AND EVALUATIONS.

8804C Trela, Irene and John Whalley! DO DEVEIOPING COUNTRIES LOSE FROM THE MFA?

8805C Whalley, John and RandaIl M. Wigle. ENDOGENOUS PARTICIPATION IN AGRICULTURAL SUPPORT PROGRAMS AND AD VALOREM EQUIVALENT MODELLING.

$8806 \mathrm{C}$ Courchene, Thomas J. THE FREE TRADE AGREEMENT: REFLECTIONS OF A MARKET NATIONALIST.

8807C Laidler, David. MONETARISM, MICROFOUNDATIONS AND THE THEORY OF MONETARY POLICY.

8808C Manning, Richard and James R. Markusen. NATIONAL PRODUCT FUNCTIONS IN COMPARATIVE STEADY-STATE ANALYSIS. 